\title{
Revision of migrated self-expandable metal stent by the remOVE device
}

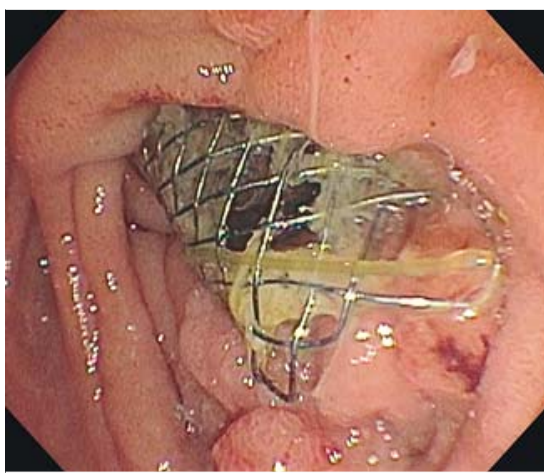

- Fig. 1 Endoscopic retrograde cholangiopancreatography revealed that the old biliary stent had migrated distally, abutting the opposite duodenal wall. Granulation tissue was visible at the distal ends of the stent.

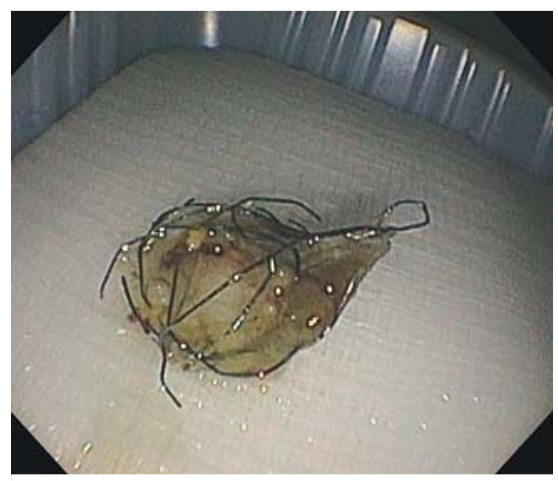

- Fig. 2 The redundant portion of the old stent was safely retrieved and removed from the patient.

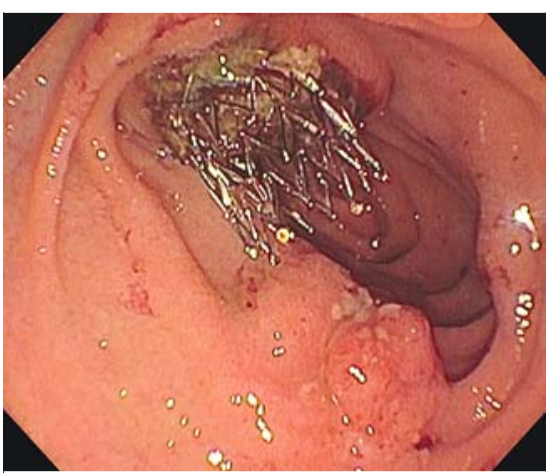

- Fig. 3 A $10 \times 60 \mathrm{~mm}$ metal stent was placed within the previous stent for therapy of recurrent malignant biliary stricture. Note that the distal ends of the new stent extend past the trimmed portion of the old stent in order to protect the surrounding tissue.

Self-expandable metal stents (SEMS) provide longer patency duration compared with plastic stents for malignant biliary obstruction [1]. Tumor in-/overgrowth, and stent migration can cause reocclusion of the biliary tract. Herein we describe the revision of a distally migrated and stenosed biliary SEMS using the remOVE system (Ovesco Endoscopy, Tübingen, Germany), a device used to fragment and retrieve over-the-scope clips (OTSC) ( Video 1 ).

A 62-year-old woman with pancreatic adenocarcinoma and biliary obstruction previously treated with SEMS presented with jaundice, abdominal pain, and fever, raising concerns for ascending cholangitis. Endoscopic retrograde cholangiopancreatography showed a distally migrated uncovered metal stent obstructing the duodenal lumen ( $\mathbf{F i g} \mathbf{1}$ ). The cholangiogram showed a single, severe stenosis within the metal stent, which was likely due to tumor ingrowth in the lower third of the common bile duct. Reintervention with a metal stent was considered the best option.

We proceeded with stent revision prior to placement of an additional SEMS. Thermal energy was applied using the remOVE system in order to fragment the

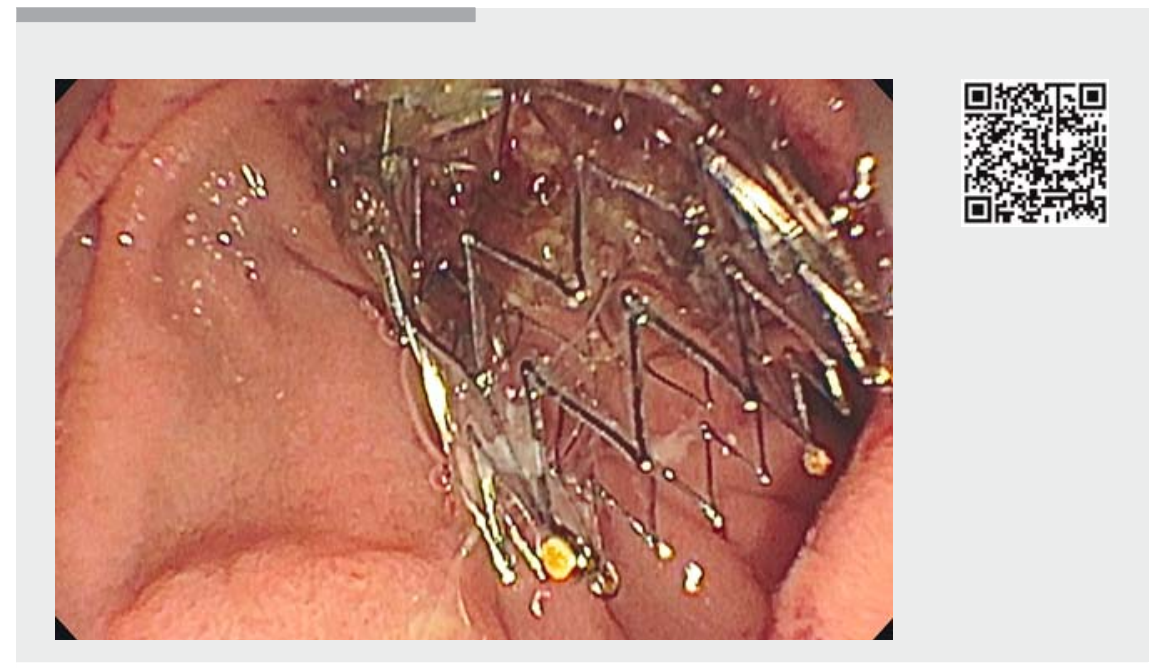

$\checkmark$ Video 1 The Ovesco reMOVE device (Ovesco Endoscopy, Tübingen, Germany) may provide a safe and effective technique for revision of migrated self-expandable metal stents.

braided wire. One to three applications of direct current from the DC Cutter were adequate to fragment and cut the wire. Trimming was completed within 12 minutes without any evident cautery effect on nearby tissue ( $\triangleright$ Fig.2). Placement of an additional SEMS was successful with proper extension length into the duodenum (> Fig. 3).
Nd:YAG laser and argon plasma coagulation have been used in the revision of migrated biliary stents; thermal injury to surrounding tissues is the most common complication [2,3]. The remOVE system, which consists of a direct current cutting instrument and a protective cap to retrieve the OTSC, has been approved for use in the United States and European Union [4]. Direct current cutting confers 
an advantage over other methods as its current is conducted over metallic components only $[3,4]$. Our experience suggests that this may be a safe and efficacious method of revising distally migrated SEMSs in malignant biliary obstruction.

Endoscopy_UCTN_Code_TTT_1AR_2AZ

\section{Competing interests}

None

The authors

\section{Tiffany Chua, Norio Fukami}

Department of Gastroenterology and Hepatology, Mayo Clinic Arizona, Phoenix Arizona, United States

\section{Corresponding author}

\section{Norio Fukami, MD}

Therapeutic Endoscopy, Department of Gastroenterology and Hepatology, Mayo Clinic Arizona, 5777 E. Mayo Blvd, Phoenix, Arizona 85054, United States

Fax: +1-480-3018673

Fukami.Norio@mayo.edu

\section{References}

[1] Egan LJ, Baron TH. Endoscopic removal of an embedded biliary Wallstent by piecemeal extraction. Endoscopy 2000; 32: 492-494

[2] Chen YK, Jakribettuu V, Springer EW et al. Safety and efficacy of argon plasma coagulation trimming of malpositioned and migrated biliary metal stents: a controlled study in the porcine model. Am J Gastroenterol 2006; 101: 2025

[3] Demarquay JF, Dumas R, Peten EP et al. Argon plasma endoscopic section of biliary metallic prostheses. Endoscopy 2001; 33: $289-290$

[4] Schmidt A, Riecken B, Damm M et al. Novel OTSC removal device. Endoscopy 2014; 46: $762-766$

\section{Bibliography}

DOI https://doi.org/10.1055/a-0666-4462

Published online: 14.8.2018

Endoscopy 2018; 50: 1129-1130

(c) Georg Thieme Verlag KG

Stuttgart · New York

ISSN 0013-726X

\section{ENDOSCOPY E-VIDEOS}

https://eref.thieme.de/e-videos

回 Endoscopy E-Videos is a free

access online section, reporting

自: on interesting cases and new

techniques in gastroenterological

endoscopy. All papers include a high

quality video and all contributions are

freely accessible online.

This section has its own submission

website at

https://mc.manuscriptcentral.com/e-videos 